\title{
RAHASIA DAGANG SEBAGAI SALAH SATU PERLINDUNGAN HAK KEKAYAAN INTELEKTUAL DARI HASIL PENELITIAN HIBAH SEKOLAH VOKASI IPB TAHUN 2020
}

(Trade Secrets as The Intellectual Property Rights Protections of The College of Vocational Studies IPB University's Grant Research in 2020)

\section{Faranita Ratih L ${ }^{1}$}

${ }^{1}$ Sekolah Vokasi, IPB University

E-mail : faranita@apps.ipb.ac.id

Diterima 2 Agustus 2021/Disetujui 23 Agustus 2021

\begin{abstract}
The Research results as the result of thoughts from researchers or lecturers need to be protected from harmful fraudulent actions. Protection of the research results also provides motivation for researchers or lecturers to continue working. One form of protection provided is the protection of Intellectual Property Rights (IPR). Various forms of IPR can be utilized as long as it meets the criteria of the IPR field. The purpose of this study was to determine the form of protection of trade secrets for the Research Results. In addition, to find out the efforts that need to be made to fulfill trade secret requirements. This research is normative legal research with a qualitative approach.

The Research results of The College of Vocational Studies IPB University's lecturer who research grants in 2020 that can be given protection as trade secrets. The Research results can be protected as trade secrets if they meet the criteria that the research results are confidential information in the field of technology and/or business, have economic value and are kept confidential by researchers or lecturers. To maintain the confidentiality of the research results, efforts were made such as providing a password, writing the word "Secret", storing documents in a safe place, making a confidentiality agreement and inserting a confidentiality clause in the license agreement.
\end{abstract}

Key Word: The Research Results, Intellectual Property Rights, Trade Secret 


\section{PENDAHULUAN}

Salah satu bentuk Tri Dharma Perguruan Tinggi adalah kegiatan penelitian yang dilaksanakan oleh dosen, penelitia atau mahasiswa. Penelitian adalah kegiatan ilmiah yang dilakukan secara sistematis dan sesuai dengan metodologi untuk mendapatkan informasi atau memecahkan suatu permasalahan. Pada kegiatan penelitian dapat dihasilkan formula baru ataupun informasi yang berguna bagi kehidupan manusia. Beberapa hasil penelitian tersebut bersifat rahasia dan diperlukan perlindungan hukum dari penyalahgunaan sehingga merugikan pihak peneliti ataupun institusi pelaksana penelitian.

Sekolah Vokasi IPB sebagai bagian dari IPB University turut melakukan kegiatan Tri Dharma Perguruan Tinggi. Secara rutin dosen Sekolah Vokasi IPB mengikuti kegiatan penelitian baik melalui skema hibah penelitian Sekolah Vokasi IPB ataupun skema hibah penelitian dari Lembaga lainnya. Pada tahun 2020 terdapat 48 judul penelitian penerima hibah penelitian dosen Sekolah Vokasi IPB, yang terbagi atas bidang sosial humaniora, pertanian dan informasi teknologi. Hasil penelitian dosen ini memiliki potensi untuk dimanfaatkan secara komersial sehingga perlu mendapatkan perlindungan hukum. Salah satu bentuk perlindungan hukum atas hasil penelitian adalah melalui sistem perlindungan Hak Kekayaan Intelektual.

Hak Kekayaan Intelektual (HKI), atau dalam Bahasa Inggris disebut sebagai Intellectual Property Rights adalah hak kebendaan yang timbul dari hasil karya pemikiran manusia. Organisasi Hak Kekayaan Intelektual/World Intellectual Property Rights memberikan keterangan HKI adalah kreasi yang dihasilkan pemikiran manusia, dan perlindungan bagi pencipta atas kreasinya. Pengertian lain dari HKI oleh Direktorat Jenderal Kekayaan Intelektual Kementerian Hukum dan HAM Republik Indonesia adalah, hak yang timbul dari hasil olah pikir yang menghasilkan suatu produk atau proses yang berguna untuk manusia (DJKI, 2020). Dari berbagai pengertian HKI terdapat dua hal penting yaitu hak milik dan hasil pemikiran manusia. Dengan dua hal tersebut maka pemegang HKI dapat memanfaatkan dan menguasai sepenuhnya hak tersebut serta berhak mencegah kepada pihak lain untuk menggunakan haknya tanpa seizinnya (Lindsey et al. 2006). Pemberian kewenangan untuk memanfaatkan HKI dan mencegah pihak lain menggunakan hak tanpa izin merupakan penghargaan atas pemikiran yang dihasilkannya.

Secara garis besar HKI terbagi atas dua yaitu hak kekayaan industri dan hak cipta. Hak kekayaan industri terdiri atas paten, merek, desain industri, rahasia dagang dan desain tata letak sirkuit terpadu. Bentuk-bentuk HKI memiliki karakteristik, persyaratan memperoleh hak dan jangka waktu perlindungan yang berbeda satu sama lainnya. Permohonan perlindungan HKI yang tidak sesuai mengakibatkan ciptaan atau karya yang dihasilkan tidak dapat dilindungi hukum.

Berdasarkan pemaparan mengenai pentingnya perlindungan $\mathrm{HKI}$, bagaimana perlindungan HKI rahasia dagang terhadap hasil penelitian hibah dosen Sekolah Vokasi IPB tahun 2020. Selain itu bagaimana upaya yang perlu dilakukan untuk melindungi hasil penelitian hibah dosen Sekolah Vokasi IPB tahun 2020 yang memiliki potensi sebagai rahasia dagang. 
Hak Kekayaan Intelektual ( $\mathrm{HKI}$ ) adalah salah satu bentuk perlindungan hukum yang dapat diberikan kepada hasil penelitian mengingat hasil penelitian dapat bernilai ekonomis yang akan menguntungkan peneliti. Bentuk perlindungan HKI akan disesuaikan dengan karakteristik hasil penelitian. Tujuan penelitian ini adalah untuk mengetahui bentuk perlindungan HKI rahasia dagang dari hibah penelitian dosen Sekolah Vokasi IPB tahun 2020. Pemberian perlindungan HKI yang tepat akan memberikan perlindungan hukum bagi peneliti dari tindakan melanggar hukum dari pihak lain dan menjadi motivasi bagi peneliti untuk terus berkarya.

\section{METODE PENELITIAN}

Penelitian ini menggunakan pendekatan kualitatif. Pada penelitian hukum normatif Rahasia Dagang, sebagai salah satu perlindungan Hak Kekayaan Intelektual dari hasil penelitian, maka dilakukan penafsiran terhadap bahan-bahan hukum (Mezak, 2006). Berdasarkan metode penelitian ini maka dilakukan pengkajian terhadap hasil penelitian dosen Sekolah Vokasi IPB penerima hibah penelitian dosen tahun 2020 yang memiliki potensi sebagai rahasia dagang, berdasarkan peraturan perundang-undangan bidang hak kekayaan intelektual di Indonesia dengan kekhususan bidang rahasia dagang. Dasar pengaturan utama rahasia dagang di Indonesia adalah Undang-Undang No. 30 Tahun 2000 Tentang Rahasia Dagang, dan peraturan pelaksana di bawahnya. Undang-Undang No. 30 Tahun 2000 tentang Rahasia Dagang merupakan implementasi dari perjanjian internasional, tentang aspek hak kekayaan intelektual yang dikenal sebagai Agreement on Trade Related Aspects of Intellectual Property Rights (TRIPs) yang telah ditanda tangani, dan diratifikasi oleh Indonesia sebagai Undang-Undang No. 7 Tahun 1994 tentang Pengesahan Agreement Establishing The World Trade Organization (Persetujuan Pembentukan Organisasi Perdagangan Dunia) (Setiawan, et.al. 2018).

Penelitian normatif dengan pendekatan kualitatif, maka dilakukan analisa peraturan perundang-undangan baik pada ranah hukum nasional ataupun konvensi internasional yang berkaitan dengan perlindungan hasil penelitian sebagai rahasia dagang. Bahan-bahan hukum yang dipergunakan pada penelitian ini adalah bahan hukum primer dan bahan hukum sekunder. Bahan hukum primer adalah peraturan perundang-undangan bidang HKI di Indonesia termasuk konvensi-konvensi internasional baik yang sudah diratifikasi ataupun belum diratifikasi oleh Indonesia. Bahan hukum sekunder yang dimanfaatkan pada penelitian ini adalah publikasi hukum seperti buku, hasil penelitian dan lain sebagainya.

\section{HASIL DAN PEMBAHASAN}

\section{Ruang Lingkup Rahasia Dagang sebagai salah satu bentuk HKI}

Rahasia dagang adalah salah satu bentuk HKI bidang hak kekayaan industri. Pada sebagian orang apabila mendengar kata rahasia dagang maka yang terbayangkan adalah resep, formula rahasia yang digunakan pada suatu produk. Rahasia dagang tidak terbatas pada resep dan formula rahasia melainkan juga 
informasi-informasi rahasia dari perusahaan yang berguna bagi operasionalnya. Salah satu rahasia dagang yang terkenal adalah formula minuman ringan Coca Cola yang terlindungi kerahasiaannya sejak tahun 1925 hingga saat ini (Schwartz, 2013). Walaupun banyak minuman ringan sejenis, rasa Coca Cola berbeda dengan minuman ringan lainnya.

Pemerintah Indonesia melalui Undang-Undang No. 30 Tahun 2020 tentang Rahasia Dagang memberikan perlindungan untuk informasi yang dikategorikan sebagai rahasia dagang. Dengan perlindungan ini maka pemilik rahasia dagang dapat terlindungi dari praktik-praktik curang yang merugikan kepentingannya. Selain itu dengan terlindunginya rahasia dagang ini maka pemilik dapat menggunakannya untuk mendapatkan keuntungan ekonomis dan melarang pihak lain untuk mengungkap rahasia dagang kepada pihak ketiga (Hull, 2009). Perbedaan bidang HKI di Indonesia terdapat pada Tabel 1.

Tidak semua informasi rahasia dikualifikasikan sebagai rahasia dagang, hanya informasi yang memenuhi persyaratan dapat dikategorikan sebagai rahasia dagang. Informasi rahasia dapat dikategorikan sebagai rahasia pribadi, rahasia negara dan rahasia dagang. Undang-Undang No. 30 Tahun 2000 tentang Rahasia Dagang memberikan pengertian rahasia dagang sebagai informasi yang tidak diketahui oleh umum di bidang teknologi dan/atau bisnis, mempunyai nilai ekonomi karena berguna dalam kegiatan usaha, dan dijaga kerahasiaannya oleh pemilik rahasia dagang. Berdasarkan pengertian ini maka terdapat empat unsur untuk informasi dikategorikan sebagai rahasia dagang yaitu bersifat rahasia, di bidang teknologi dan/atau bisnis, memiliki nilai ekonomi dan dijaga kerahasiaannya. Apabila keempat kriteria tersebut terpenuhi maka informasi tersebut dikategorikan sebagai rahasia dagang dan dapat diberikan perlindungan hukum HKI sebagai rahasia dagang. Perlindungan hukum rahasia dagang akan diberikan tidak terikat jangka waktu tertentu selama keempat unsur rahasia dagang terpenuhi. Informasi rahasia yang di kemudian hari diketahui publik maka saat itu perlindungan hukum atas rahasia dagang usai.

Tidak semua informasi rahasia dikualifikasikan sebagai rahasia dagang, hanya informasi yang memenuhi persyaratan dapat dikategorikan sebagai rahasia dagang. Informasi rahasia dapat dikategorikan sebagai rahasia pribadi, rahasia negara dan rahasia dagang. Undang-Undang No. 30 Tahun 2000 tentang Rahasia Dagang memberikan pengertian rahasia dagang sebagai informasi yang tidak diketahui oleh umum di bidang teknologi dan/atau bisnis, mempunyai nilai ekonomi karena berguna dalam kegiatan usaha, dan dijaga kerahasiaannya oleh pemilik rahasia dagang. Berdasarkan pengertian ini maka terdapat empat unsur untuk informasi dikategorikan sebagai rahasia dagang yaitu bersifat rahasia, di bidang teknologi dan/atau bisnis, memiliki nilai ekonomi dan dijaga kerahasiaannya. Apabila keempat kriteria tersebut terpenuhi maka informasi tersebut dikategorikan sebagai rahasia dagang dan dapat diberikan perlindungan hukum HKI sebagai rahasia dagang. Perlindungan hukum rahasia dagang akan diberikan tidak terikat jangka waktu tertentu selama keempat unsur rahasia dagang terpenuhi. Informasi rahasia yang di kemudian hari diketahui publik maka saat itu perlindungan hukum atas rahasia dagang usai. 
Ruang lingkup rahasia dagang menurut Undang-Undang No. 30 Tahun 2000 tentang Rahasia Dagang adalah metode produksi, metode pengolahan, metode penjualan, atau informasi di bidang teknologi dan/atau bisnis yang memiliki nilai ekonomis dan tidak diketahui masyarakat. Secara garis besar ruang lingkup rahasia dagang adalah informasi teknis dan informasi non teknis/bisnis. Informasi teknis yang berupa informasi tentang penelitian dan pengembangan, informasi pada kegiatan proses manufaktur, dan know how. Informasi non teknis diantaranya adalah informasi tentang pelanggan dan kebijakan perusahaan. Informasi teknis tentang penelitian dan pengembangan yang dimaksud adalah berbagai formula/rumus-rumus, campuran bahan-bahan/senyawa kimiawi, prototipe, catatan hasil penelitian dan percobaan, desain, laporan penelitian, dan hal-hal yang terkait dengan proses pengembangan suatu produk.

Tabel 1 Klasifikasi Hak Kekayaan Intelektual Di Indonesia

\begin{tabular}{|c|c|c|c|c|c|c|c|}
\hline & $\begin{array}{l}\text { Hak } \\
\text { Cipta }\end{array}$ & Paten & Merek & $\begin{array}{l}\text { Rahasia } \\
\text { Dagang }\end{array}$ & $\begin{array}{l}\text { Desain } \\
\text { Industri }\end{array}$ & $\begin{array}{c}\text { Desain } \\
\text { Tata } \\
\text { Letak } \\
\text { Sirkuit } \\
\text { Terpad } \\
\text { u } \\
\text { (DTLST } \\
\text { ) }\end{array}$ & $\begin{array}{c}\text { Perlindu } \\
\text { ngan } \\
\text { Varietas } \\
\text { Tanaman }\end{array}$ \\
\hline $\begin{array}{l}\text { Undang- } \\
\text { Undang }\end{array}$ & $\begin{array}{l}\text { UU No. } \\
28 \\
\text { Tahun } \\
2014\end{array}$ & $\begin{array}{l}\text { UU No. } \\
13 \\
\text { Tahun } \\
2016\end{array}$ & $\begin{array}{l}\text { UU No. } \\
20 \\
\text { Tahun } \\
2016\end{array}$ & $\begin{array}{l}\text { UU No. } \\
30 \text { Tahun } \\
2000\end{array}$ & $\begin{array}{l}\text { UU No. } \\
31 \\
\text { Tahun } \\
2000\end{array}$ & $\begin{array}{l}\text { UU No. } \\
32 \\
\text { Tahun } \\
2000\end{array}$ & $\begin{array}{l}\text { UU No. } \\
29 \text { Tahun } \\
2000\end{array}$ \\
\hline Subyek & Pencipta & Inventor & $\begin{array}{l}\text { Pemilik } \\
\text { Merek }\end{array}$ & $\begin{array}{l}\text { Pemilik } \\
\text { Rahasia } \\
\text { Dagang }\end{array}$ & $\begin{array}{l}\text { Pendes } \\
\text { ain }\end{array}$ & $\begin{array}{l}\text { Pendes } \\
\text { aian } \\
\text { DTLST }\end{array}$ & $\begin{array}{l}\text { Pemulia } \\
\text { Tanaman }\end{array}$ \\
\hline Obyek & $\begin{array}{l}\text { Ilmu } \\
\text { pengeta } \\
\text { huan, } \\
\text { seni dan } \\
\text { sastra }\end{array}$ & $\begin{array}{l}\text { Invensi, } \\
\text { proses, } \\
\text { produk }\end{array}$ & $\begin{array}{l}\text { Tanda } \\
\text { barang } \\
\text { dan jasa }\end{array}$ & $\begin{array}{l}\text { Informasi } \\
\text { bisnis } \\
\text { rahasia }\end{array}$ & $\begin{array}{l}\text { Penamp } \\
\text { ilan } \\
\text { produk }\end{array}$ & $\begin{array}{l}\text { Desain } \\
\text { tata } \\
\text { letak } \\
\text { sirkuit } \\
\text { terpadu }\end{array}$ & $\begin{array}{l}\text { Varietas } \\
\text { tanaman }\end{array}$ \\
\hline $\begin{array}{l}\text { Cara } \\
\text { Mendapat } \\
\text { kan } \\
\text { Perlindun } \\
\text { gan }\end{array}$ & $\begin{array}{l}\text { Tanpa } \\
\text { pendafta } \\
\text { ran }\end{array}$ & $\begin{array}{l}\text { Pendaft } \\
\text { aran }\end{array}$ & $\begin{array}{l}\text { Pendaft } \\
\text { aran }\end{array}$ & $\begin{array}{l}\text { Tanpa } \\
\text { pendaftar } \\
\text { an }\end{array}$ & $\begin{array}{l}\text { Pendaft } \\
\text { aran }\end{array}$ & $\begin{array}{l}\text { Pendaft } \\
\text { aran }\end{array}$ & $\begin{array}{l}\text { Pendaftar } \\
\text { an }\end{array}$ \\
\hline $\begin{array}{l}\text { Syarat } \\
\text { Substantif }\end{array}$ & $\begin{array}{l}\text { Orisinalit } \\
\text { as }\end{array}$ & $\begin{array}{l}\text { Novelty } \\
\text { langkah } \\
\text { inventif, } \\
\text { diterapk } \\
\text { an di } \\
\text { industri }\end{array}$ & $\begin{array}{l}\text { Tanda } \\
\text { pembed } \\
\text { a pada } \\
\text { perdaga } \\
\text { ngan }\end{array}$ & $\begin{array}{l}\text { Informasi } \\
\text { bernilai } \\
\text { ekonomi } \\
\text { dan } \\
\text { dirahasia } \\
\text { kan }\end{array}$ & $\begin{array}{l}\text { Kebarua } \\
n\end{array}$ & $\begin{array}{l}\text { Orisinal } \\
\text { itas }\end{array}$ & $\begin{array}{l}\text { Baru, } \\
\text { unik, } \\
\text { seragam, } \\
\text { stabil, } \\
\text { diberi } \\
\text { penamaa } \\
\text { n }\end{array}$ \\
\hline $\begin{array}{l}\text { Jangka } \\
\text { Waktu }\end{array}$ & $\begin{array}{l}\text { Pencipta } \\
\text { meningg } \\
\text { al dunia }\end{array}$ & $\begin{array}{l}10 \text { thn, } \\
\text { paten }\end{array}$ & $\begin{array}{l}10 \text { thn } \\
\text { sejak } \\
\text { tanggal }\end{array}$ & $\begin{array}{l}\text { Selama } \\
\text { informasi }\end{array}$ & $\begin{array}{l}10 \text { thn } \\
\text { sejak } \\
\text { tanggal }\end{array}$ & $\begin{array}{l}10 \text { thn } \\
\text { sejak } \\
\text { didaftar }\end{array}$ & $\begin{array}{l}20 \text { thn } \\
\text { (tanaman } \\
\text { musiman) }\end{array}$ \\
\hline
\end{tabular}




\begin{tabular}{llllllll}
\hline $\begin{array}{l}\text { Perlindun } \\
\text { gan }\end{array}$ & ditamba & sederha & penerim & dirahasia & penerim & /diekspl & 25 thn \\
h 70 thn & na & aan dan & kan & aan & oitasi & $\begin{array}{l}\text { (tanaman } \\
\text { tahunan) }\end{array}$ \\
& berikutn & 20 thn, & dapat & & & & \\
& ya & paten & $\begin{array}{l}\text { diperpa } \\
\text { njang }\end{array}$ & & & \\
\hline
\end{tabular}

\section{Hasil Penelitian Sebagai Bentuk Rahasia Dagang}

Kamus Besar Bahasa Indonesia memberikan definisi penelitian sebagai kegiatan pengumpulan, pengolahan, analisis serta penyajian data secara sistematis dan obyektif, untuk memecahkan masalah atau menguji hipotesis. Menurut Undang-Undang No. 12 Tahun 2012 tentang Pendidikan Tinggi dijelaskan bahwa "Penelitian adalah kegiatan yang dilakukan menurut kaidah dan metode ilmiah secara sistematis untuk memperoleh informasi, data dan keterangan yang berkaitan dengan pemahaman dan/atau pengujian suatu cabang ilmu pengetahuan dan teknologi". Penelitian sebagai suatu kegiatan ilmiah maka di dalamnya terkait dengan metodologi, analisa yang dilaksanakan secara sistematis dan sesuai dengan kaidah keilmuan. Melalui penelitian ini maka akan dapat dihasilkan penjelasan, pemahaman atas suatu hal, produk atau proses baru yang kebenarannya teruji secara ilmiah.

Pada kegiatan penelitian maka akan terlibat informasi-informasi baik yang digunakan saat penelitian ataupun dihasilkan dari penelitian. Sebagai bentuk hasil pemikiran maka hasil kegiatan penelitian baik yang dilakukan oleh dosen atau peneliti dapat dikategorikan sebagai HKI. Perlindungan HKI yang diberikan adalah sebagai paten, desain industri, hak cipta atau rahasia dagang. Pada tahun 2020 Sekolah Vokasi IPB memberikan 48 hibah penelitian kepada dosen-dosennya yang dapat dikategorikan pada bidang sosial humaniora, pertanian dan informasi teknologi. Penelitian ini memiliki potensi mendapatkan perlindungan HKI seperti pada Tabel 2.

Tabel 2 Potensi HKI Hibah Penelitian Dosen Sekolah Vokasi IPB Tahun 2020

\begin{tabular}{cccc}
\hline No & Bidang & $\begin{array}{c}\text { Jumlah } \\
\text { Penelitian }\end{array}$ & Potensi HKI \\
\hline 1 & Sosial Humaniora & 10 & Hak Cipta \\
2 & Pertanian & 22 & $\begin{array}{c}\text { Paten, Rahasia Dagang, } \\
\text { Desain Industri, Merek }\end{array}$ \\
3 & Informasi & 16 & Paten, Hak Cipta \\
\hline
\end{tabular}

Hasil penelitian dosen Sekolah Vokasi IPB penerima hibah penelitian tahun 2020 dapat berupa aplikasi atau program komputer, formula, peralatan tepat guna dan informasi lainnya yang dapat dimanfaatkan oleh masyarakat. Berdasarkan Tabel 2 di atas, maka penelitian dosen Sekolah Vokasi dapat diberikan perlindungan HKI sesuai karakteristik dan persyaratan HKI. Hak paten diberikan kepada inovasi yang memenuhi unsur kebaruan atau novelty dan dapat diterapkan di industri. Perlindungan hak cipta diberikan atas karya cipta bidang ilmu 
pengetahuan dan seni yang merupakan wujud dari ide pencipta. Hasil penelitian dosen yang diterbitkan dalam bentuk prosiding ataupun jurnal dapat diberikan perlindungan hak cipta. Dosen Sekolah Vokasi IPB perlu mengetahui bentukbentuk HKI yang dihasilkan dari penelitiannya agar tidak terjadi penolakan pendaftaran $\mathrm{HKI}$. Bentuk HKI dari hasil penelitian yang diinginkan oleh peneliti tidak hanya ditentukan saat penelitian usai dilaksanakan tetapi dirancang saat penyusunan proposal penelitian. Perlindungan hukum atas hasil penelitian memiliki peranan penting agar tidak terjadi penyalahgunaan hasil yang merugikan peneliti yang telah mencurahkan tenaga dan pikirannya.

Pada kegiatan penelitian akan melibatkan berbagai informasi baik yang digunakan saat penelitian ataupun sebagai hasil penelitian. Informasi tersebut dapat bersifat rahasia yang hanya dapat diketahui oleh pihak tertentu atau bersifat umum yang bisa diketahui oleh publik. Informasi-informasi ini dapat diberikan perlindungan $\mathrm{HKI}$ sesuai persyaratannya. Sebagai contoh tidak semua hasil penelitian memenuhi kualifikasi sebagai paten karena tidak memiliki unsur kebaruan atau hak cipta karena bukan pada bidang perlindungan hak cipta. Salah satu bentuk perlindungan HKI yang dapat dimanfaatkan bagi hasil penelitian yang tidak memenuhi kriteria paten, hak cipta, atau desain industri adalah rahasia dagang. Perlindungan rahasia dagang dapat diberikan terhadap hasil penelitian sepanjang memenuhi unsur yang ditetapkan oleh peraturan perundang-undangan. Melalui sistem perlindungan rahasia dagang maka jangka waktu perlindungannya tidak terbatas sepanjang terjaga kerahasiaannya.

Hasil penelitian yang dapat diberikan perlindungan hukum sebagai rahasia dagang apabila memenuhi kriteria yang ditetapkan oleh Undang-Undang No 30 Tahun 2000 tentang Rahasia Dagang. Pemenuhan kriteria tersebut sebagai berikut :

1. Informasi bersifat rahasia atau tidak diketahui umum

Berdasarkan ruang lingkup rahasia dagang maka hasil penelitian dikategorikan sebagai informasi teknis. Informasi teknis rahasia ini tidak hanya hasil penelitian, laporan penelitian tetapi juga informasi-informasi yang terkait pada proses selama dilakukannya penelitian. Hasil penelitian sebagai informasi rahasia bermakna bahwa hasil penelitian tersebut hanya diketahui oleh peneliti atau pihakpihak tertentu yang diberikan kewenangan untuk mengetahuinya (Susilowaty, 2013). Suatu informasi menjadi rahasia karena didapatkan dari hasil pemikiran pemilik informasi serta hanya dapat diperoleh oleh pihak lain apabila ia melakukan tindakan yang sama seperti yang dilakukan oleh pemilik informasi rahasia (Golvan, 1992). Dengan demikian peneliti harus mampu membuktikan hasil penelitian yang bersifat rahasia hanya diketahui oleh dirinya atau pihak lain yang diberikan hak untuk mengetahui informasi rahasia tersebut.

Terhadap kewajiban pelaporan hasil penelitian maka peneliti harus memilah informasi yang harus disampaikan dan informasi yang tetap dirahasiakan. Selain kewajiban pelaporan hasil penelitian maka peneliti juga harus memutuskan kriteria perlindungan $\mathrm{HKI}$ yang dipilinnya. Pemilihan bidang $\mathrm{HKI}$ atas hasil penelitian akan menentukan bentuk perlindungannya. Apabila peneliti memilih perlindungan paten maka kriteria hasil penelitian sebagai informasi rahasia akan gugur. Hal ini karena 
pada pendaftaran paten salah satu syaratnya adalah pengumuman atau publikasi atas temuan tersebut untuk membuktikan bahwa temuan tersebut memenuhi unsur novelty atau kebaruan. Saat pengumuman paten maka informasi tersebut tidak lagi bersifat rahasia dan perlindungan $\mathrm{HKI}$ sebagai rahasia dagang usai. Hal yang sama berlaku apabila hasil penelitian didaftarkan sebagai hak cipta atau hak desain industri karena sistem pendaftaran $\mathrm{HKI}$ keduanya mensyaratkan pengumuman ciptaan atau desain.

2. Informasi pada bidang teknologi dan/atau bisnis

Penelitian yang dilakukan oleh perguruan tinggi sebagai penelitian ilmu dasar ataupun ilmu terapan. Hasil penelitian yang akan mendapatkan perlindungan sebagai rahasia dagang maka dapat diterapkan pada ruang lingkup perdagangan dan perindustrian. Pada bidang teknologi maka informasi rahasia dari hasil penelitian dapat berupa campuran bahan, formula, resep dan lain sebagainya. Informasi rahasia bidang bisnis diantaranya strategi perdagangan, informasi keadaan konsumen dan kebijakan perusahaan.

\section{Informasi memiliki nilai ekonomi}

Pada Undang-Undang No. 30 Tahun 2000 tentang Rahasia Dagang dijelaskan nilai ekonomis dari informasi rahasia apabila informasi tersebut dapat dipergunakan untuk mendapatkan keuntungan secara ekonomi ataupun sebagai keunggulan kompetitif atas pesaingnya pada suatu kegiatan usaha. Pemilik rahasia dagang akan mempergunakan informasi rahasia untuk keuntungan dirinya baik dilakukan sendiri ataupun memberi lisensi kepada pihak lain. Hasil penelitian diharapkan tidak hanya menjadi kertas kerja yang tersimpan di laci peneliti namun dapat dimanfaatkan baik untuk kepentingan komersial ataupun non komersial berdasarkan perjanjian antara peneliti dan lembaga yang menaunginya. Pemanfatan hasil penelitian secara komersial dapat memberikan keuntungan bagi peneliti atau lembaga.

\section{Informasi dijaga kerahasiaannya oleh pemilik rahasia dagang}

Pemilik rahasia dagang harus menjaga kerahasiaan informasi yang dimilikinya. Apabila ia lalai sehingga kerahasiaan informasi terungkap maka berakhir pula perlindungan hukum atas informasi tersebut. Pada penjelasan pasal 3 ayat 1 Undang-Undang No. 30 Tahun 2000 tentang Rahasia Dagang bahwa pemilik rahasia dagang harus melakukan upaya sebagaimana mestinya untuk menjaga kerahasiaan informasi. Upaya yang dilakukan tersebut adalah semua langkah sesuai dengan ukuran kewajaran, kelayakan dan kepatutan untuk menjaga rahasia. Terbukanya kerahasiaan informasi maka mengakibatkan kerugian bagi pemilik rahasia dagang karena informasi tersebut dapat dimanfaatkan oleh pesaing atau lawan bisnisnya (Setyawicaksana, 2000).

Salah satu judul penelitian penerima hibah penelitian dosen Sekolah Vokasi IPB tahun 2020 yang memiliki potensi sebagai rahasia dagang adalah Pengaruh Penambahan Ceker Ayam Dalam Pembuatan Keik Chiffon Ditinjau Dari Kandungan Gizi Dan Uji Organoleptik. Penelitian ini akan menghasilkan formulaformula khusus pembuatan keik chiffon yang ditambahkan ceker ayam. Keik 
chiffon yang dihasilkan pada penelitian ini memberikan manfaat bagi kesehatan sehingga memiliki potensi ekonomis apabila produk ini dijual ke masyarakat. Tim peneliti menyadari potensi HKI sebagai rahasia dagang pada pembuatan keik chiffon dengan ceker ayam maka merahasiakan berbagai informasi yang terlibat pada penelitian ini. Selain itu untuk menjaga kerahasiaan seluruh pihak yang terlibat pada penelitian menandatangani perjanjian kerahasiaan antara ketua tim peneliti dan pihak yang terlibat penelitian.

\section{Upaya Perlindungan Hasil Penelitian Sebagai Rahasia Dagang}

Rahasia dagang berbeda dengan bidang HKI lain yang mewajibkan pendaftaran untuk mendapatkan perlindungan hukum. Perlindungan rahasia dagang diberikan apabila informasi rahasia tersebut memenuhi kriteria yang disebutkan oleh peraturan perundang-undangan dan tidak perlu didaftarkan. Salah satu kriteria yang harus dipenuhi adalah upaya-upaya menjaga kerahasiaan rahasia dagang. Beberapa hal dapat dilakukan oleh dosen atau peneliti untuk memenuhi kriteria ini yaitu:

\section{Penentuan Jenis Perlindungan HKI}

Peneliti saat melakukan penelitian perlu mempertimbangkan jenis HKI yang mungkin dihasilkan. Penentuan jenis HKI akan membedakan proses dan perlindungan hukum yang diberikan. Apabila hasil penelitian didaftarkan sebagai paten maka hasil penelitian tersebut tidak dapat dikategorikan sebagai rahasia dagang karena informasinya akan diketahui umum sebagai salah satu syarat pendaftaran paten. Hal yang sama apabila hasil penelitian didaftarkan di bidang HKI lain karena pada umumnya proses mendapatkan perlindungan $\mathrm{HKI}$ akan dilakukan pengumuman atau publikasi atas hasil penelitian. Tujuan pengumuman atau publikasi pendaftaran HKI adalah membuktikan bahwa objek HKI yang didaftarkan memiliki unsur kebaruan dan tidak dimiliki oleh pihak lain.

\section{Upaya-Upaya Menjaga Kerahasiaan Hasil Penelitian}

Upaya menjaga kerahasiaan adalah salah satu syarat untuk memperoleh perlindungan hukum sebagai rahasia dagang. Peneliti perlu melakukan tindakantindakan untuk mengamankan kerahasiaan hasil penelitiannya. Beberapa upaya yang dilakukan oleh peneliti tersebut adalah:

a. Menyimpan dokumen hasil penelitian

Peneliti perlu menyimpan dokumen penelitian yang mengandung informasi rahasia secara baik. Pada dokumen dicantumkan kata "RAHASIA" sebagai salah satu cara untuk menjaga kerahasiaan. Cara lainnya adalah menyimpan dokumen tersebut pada lemari besi atau tempat penyimpanan yang aman dan hanya diketahui oleh beberapa orang secara terbatas. Apabila dokumen dalam bentuk soft file maka dapat diberikan password. Password yang digunakan sudah tentu yang tidak mudah ditebak seperti tanggal lahir tetapi bagi peneliti cukup mudah untuk mengingatnya. Selain menyimpan dokumen pada lemari besi, soft file dokumen hasil penelitian dapat tersimpan di cloud storage yang saat ini banyak tersedia dengan beragam pilihan. Peneliti patut mempertimbangkan cloud storage 
yang bagus dengan memberikan keamanan sebagai tempat penyimpanan soft file hasil penelitian yang telah diberikan password sebelumnya.

b. Membuat perjanjian kerahasiaan kepada pihak-pihak yang terlibat pada penelitian.

Ketua tim peneliti perlu membuat perjanjian kerahasiaan (confidential agreement) antara ketua tim dan pihak-pihak yang terlibat penelitian. Pada perjanjian ini dimasukan klasula bahwa semua pihak yang terlibat penelitian harus menjaga semua informasi yang timbul dari penelitian. Klasula kewajiban menjaga kerahasiaan tidak hanya saat kegiatan penelitian berlangsung tetapi dapat diperpanjang hingga jangka waktu tertentu setelah kegiatan penelitian berakhir. Selain klausula menjaga kerahasiaan dapat ditambahkan sanksi apabila para pihak melanggar perjanjian kerahasiaan. Perjanjian kerahasiaan dapat dibuat dan ditandatangani tanpa notaris atau perjanjian dibuat dihadapan notaris. Perbedaan jenis perjanjian tersebut adalah kekuatan pembuktiannya.

c. Klasula kerahasiaan pada perjanjian lisensi.

Peneliti dapat menggunakan hasil penelitian sendiri atau memberikan hak kepada pihak lain untuk menggunakan hasil penelitiannya. Pemberian izin untuk menikmati manfaat dari objek HKI untuk jangka waktu tertentu disebut lisensi (Saidin, 2015). Pada perjanjian lisensi peneliti berkedudukan sebagai pemberi lisensi dan pihak yang ditunjuk sebagai penerima lisensi. Penerima lisensi berhak menggunakan hasil penelitian untuk mendapatkan manfaat ekonomi selama jangka waktu tertentu dan berkewajiban membayar royalti kepada pemberi lisensi. Pemberian lisensi dituangkan pada Perjanjian Lisensi Rahasia Dagang. Pada perjanjian lisensi yang ditanda tangani kedua belah pihak wajib menyertakan klausula menjaga rahasia dagang selama jangka waktu perjanjian dan periode tertentu setelah perjanjian berakhir. Perjanjian lisensi rahasia dagang wajib didaftarkan di Dirjen Kekayaan Intelektual Kementerian Hukum dan HAM. Apabila perjanjian lisensi tidak didaftarkan maka tidak berakibat hukum bagi pihak ketiga yang secara tidak sengaja mengetahui kerahasiaan informasi yang terkandung pada perjanjian tersebut.

\section{d. Pelaporan hasil penelitian.}

Publikasi hasil penelitian adalah salah satu kegiatan yang dilakukan setelah penelitian selesai. Laporan penelitian dapat dituangkan pada Laporan Penelitian, Jurnal atau bentuk-bentuk lainnya. Sama halnya dengan kegiatan penelitian di institusi lain, dosen Sekolah Vokasi juga berkewajiban untuk memberikan laporan atas penelitiannya. Hasil penelitian yang akan diberikan perlindungan rahasia dagang maka dosen atau peneliti diharuskan merahasiakan atau tidak mempublikasikan bagian informasi yang bersifat rahasia tersebut dengan tidak melanggar kaidah pelaporan hasil penelitian.

\section{SIMPULAN}

Hasil penelitan diperlukan perlindungan hukum dari tindakan curang atau tindakan pelanggaran hukum yang dapat merugikan kepentingan peneliti. 
Perlindungan hukum atas hasil penelitian juga menjadi motivasi bagi peneliti untuk melakukan penelitian lainnya. Bentuk-bentuk perlindungan hukum atas hasil penelitian salah satunya adalah melalui perlindungan hak kekayaan intelektual dengan bentuknya seperti paten, hak cipta, hak desain industri, merek atau rahasia dagang. Pemberian perlindungan ini disesuaikan dengan persyaratan dari setiap bentuk hak kekayaan intelektual. Salah satu bentuk perlindungan hak kekayaan intelektual untuk hasil penelitian adalah rahasia dagang. Perlindungan ini diberikan karena hasil penelitian tersebut tidak memenuhi kriteria paten, merek, hak cipta, desain industri, desain tata letak sirkuit terpadu tetapi berharga karena memiliki nilai ekonomis dan bersifat rahasia. Pada hibah penelitian dosen Sekolah Vokasi IPB tahun 2020 diketahui beberapa hasil penelitian memiliki potensi perlindungan $\mathrm{HKI}$ sebagai rahasia dagang karena memenuhi kualifikasi sebagai rahasia dagang.

\section{SARAN}

Hasil penelitian dosen Sekolah Vokasi Tahun 2020 yang memenuhi syarat sebagai rahasia dagang perlu dilakukan upaya untuk menjaga kerahasiaan sebagai salah satu syarat perlindungan HKI rahasia dagang. Upaya-upaya yang dilakukan adalah pembuatan perjanjian kerahasiaan (Confidential Agreement) yang ditanda tangani oleh ketua tim peneliti dan pihak-pihak yang terlibat pada penelitian dan menyimpan dokumen hasil penelitian yang telah dituliskan kata "RAHASIA" pada tempat yang layak termasuk juga memilah informasi hasil penelitian pada laporan hasil penelitian

\section{DAFTAR PUSTAKA}

Direktorat Jenderal Hak Kekayaan Intelektual. 2020. Modul Ki-Lat Untuk Pemula: Kenali Hak Kekayaan Intelektual Dengan Singkat dan Tepat (Hak Cipta, Merek, Desain Industri, \& Paten). Jakarta: Direktorat Jenderal Kekayaan Intelektual Kementerian Hukum dan Hak Asasi Manusia Republik Indonesia.

Golvan, Collin.1992. An Introduction to Intellectual Property Law. Leichardt: The Federation Press, Pty.Ltd.

Hull, John. 2009. "Trade Secret Licensing: The Art of The Possible", Journal of Intellectual Property Law \& Practice, Vol. 4, Issue 3, 203-212.

Indonesia. Undang-Undang Tentang Rahasia Dagang. UU No. 30, LN No. 242 Tahun 2000, TLN No. 4044.

Lindsey, Tim, et.al. 2006. Hak Kekayaan Intelektual, Suatu Pengantar. Bandung: Asian Law Group Pty.Ltd \& PT Alumni.

Mezak, Meruy Hendrik. 2006 “Jenis, Metode dan Pendekatan Dalam Penelitian Hukum”, Law Review, Fakultas Hukum Universitas Pelita Harapan, Vol. V, No.3, 85-97.

Saidin, Ok. 2015. Aspek Hukum Hak Kekayaan Intelektual (Intellectual Property Rights). Jakarta: PT Raja Grafindo Persada.

Schwartz, Andrew. 2013. "The Corporate Preference for Trade Secret". Colorado Law Scholarly Commons: 74 OHIO ST. L.J. 623.

Setiawan, A, Sulistianingsih, D, Kusumangingtyas RD. 2018. "Eksistensi Pendaftaran Rahasia Dagang Dan Implementasi Perlindungannya (Studi 
Kasus Di Kanwil Kemenkumham Jawa Tengah)", Law and Justice Jurnal,

Fakultas Hukum Universitas Muhammadiyah Surakarta, Vol. 3 No. 2, 73-81.

Setyawicaksana, A. 2000. "Rahasia Dagang dan Upaya Perlindungannya" Forum Hukum No. 6/V/2000, 97-98

Susilowaty, Etty. 2013. Hak Kekayaan Intelektual dan Lisensi Pada HKI.

Semarang:Badan Penerbit Undip Press. 